\title{
Multiple Intelligences among Ninth-Grade Students in the Sultanate of Oman
}

\author{
Afraa Ali Al Hosni ${ }^{1, *} \&$ Rayya Salim Al-Manthari ${ }^{1}$ \\ ${ }^{1}$ Department of Curriculum and Instruction, Arabic Language, College of Education, Sultan Qaboos University, \\ Sultanate of Oman \\ *Correspondence: Department of Curriculum and Instruction, Arabic Language, College of Education, Sultan Qaboos \\ University, Sultanate of Oman. E-mail: afrahosni@moe.om
}

Received: February 16, 2021

Accepted: March 26, $2021 \quad$ Online Published: April 12, 2021

doi:10.5430/wje.v11n2p15

URL: https://doi.org/10.5430/wje.v11n2p15

\begin{abstract}
This study aimed to examine the multiple intelligences among the ninth-grade students in the North Al Batinah Governorate in the Sultanate of Oman. The study sample contained 112 randomly selected students. For the purposes of this study, the researchers designed two multiple intelligences scales, consisting of the eight types of intelligences: linguistic-verbal, visual-spatial, logical-mathematical, interpersonal, naturalistic, bodily-kinesthetic, intrapersonal, and rhythm-musical. Each type of intelligence includes 8 descriptive items, with a total of 64 items for the whole scale. The results showed that the first, second, and third ranks came in favor of interpersonal intelligence, mathematical-logical, and visual-spatial, respectively, among students in general, whereas the results also revealed that interpersonal intelligence, logical-mathematical, and naturalistic were ranked in the first three ranks among male students. The interpersonal intelligence, visual-spatial intelligence, and the mathematical-logic intelligence were ranked in the first three places, respectively, among the female students. The results showed there are statistically significant differences at the 0.05 significance level between the arithmetic means of students in multiple intelligences due to the gender variable in favor of women in each of the visual-spatial and intrapersonal intelligences. Based on the findings of the study, a number of recommendations were proposed, most notably the following: Applying multiple intelligences scales at the beginning of each academic year, classifying students according to their intelligence to build and implement lesson plans in light of these classifications, preparing educational curricula in light of students' multiple intelligences to take into account the differences between them, diversifying the learning environments according to the intelligence differences among students, conducting diagnostic studies for the prevalent multiple intelligences among all students in all classes and educational stages, and engaging in studies that test the effectiveness of employing the theory of multiple intelligences and its educational applications in developing language and intrapersonal skills and enhancing academic achievement.
\end{abstract}

Keywords: multiple intelligences, ninth-grade students, Sultanate of Oman

\section{Introduction}

The concept of intelligence has been associated for many years with academic success. The educational system had neglected many of the abilities and capabilities of students until recently, and it has only taken into account some of their abilities, such as mathematical, linguistic, and logical ability, while neglecting many other capabilities, despite their value. This system has dealt with intelligence as the ability or set of capabilities that help individuals learn, solve problems, and interact properly with their environment (Al-Hashemi \& Maharmah, 2014, p. 203).

Intelligence is defined, therefore, as "Psychological and biological capacity to process information, solve problems, or create value products in one or more cultural environments that are relevant to the communities in which they are living (Gardner \& Moran, 2006, p. 227).

Education can highly contribute to the students' development through directing them toward areas that are in harmony with their abilities. In this way, teachers can discover their competencies and their natural talents, and then they can develop those competencies through several methods and tools. Teachers can also identify one or more types of intelligences among their students through several indicators (Al-Hashemi \& Maharmah, 2014, p. 213). 
The theory of intelligences is based on two basic assumptions: First, all people have the same interest and abilities, but they do not learn in the same way. Second, each person has capabilities within the range of the eight types of intelligences, but there are those who possess very high levels of functional performance in all eight intelligences such as geniuses, whereas others possess very low levels of functional performance, such as the disabled. Most people are distributed in the middle of these two points. There is no specific application model to apply this theory in teaching, and teachers may employ many strategies that enrich the teaching process (Al-Hashemi \& Al-Dulaimi, 2008, p. $82-83)$.

This theory describes multiple dimensions in intelligence and focuses on problem-solving and creative production, based on the assumption that intelligence can transform into a form of problem-solving or production. This theory does not focus on intelligence being genetic only — but rather as an environmental development (Al-Zahrani, 2003, p. 511).

Howard Gardner's theory of multiple intelligences has changed the way people all over the world think about learning; teachers using this theory have achieved remarkable success in helping all students, including those who learn traditionally (Armstrong \& Association for Supervision and Curriculum Development, 2018).

The importance of this theory in the field of education is evident in the way it facilitates the selection of strategies and activities appropriate to these intelligences, as well as improving reading and writing skills of the learners. This theory also supports talented and creative people, stimulates them to be creative, and enhances their self-confidence and independent thinking (Hussein, 2013, p. 61).

Nolen (2003) believed that the lesson plans that take into account the different types of intelligences of students can facilitate the teaching process, create better learning experiences, and help teachers address the individual differences of multiple intelligences.

Hussain (2005. P 64), Northey (2013, p. 20-21), Al-Hashemi and Maharmah (2014, p. 213 -223), and Armstrong $(2009$, p. 7$)$ listed the types of intelligences and their characteristics, as follows:

Linguistic-Verbal Intelligence: In this type, students are able to conduct discussions, brainstorming, and debates; write stories and articles; engage in listening activities and role-playing; and play educational linguistic games.

Logical-Mathematical Intelligence: The students possess the skills of problem-solving, comparisons, inferential thinking, and educational logical games.

Spatial Intelligence: The students are good at visualizing things, maps and graphics, group dramatic acting, writing fiction, and visualizing characters.

Bodily-Kinesthetic Intelligence: The students are good at group projects, role-playing and drama, learning-by-doing, body movement, and sports activities.

Musical Intelligence: The students in this type are good at group songs, discussions of all kinds, cooperative learning, and group projects in the school and in the surrounding environment.

Interpersonal Intelligence: The students are interested in working in groups, having discussions of all kinds, and engaging in cooperative learning.

Intrapersonal Intelligence: The students are good at individual working, reflection, independent studies, self-evaluation, and awareness of motives and desires.

Naturalistic Intelligence: The students are interested in field trips, animals and plants, the environment, and model awareness.

Academic achievement is closely related to intelligence. Therefore, students' academic growth should be understood, and attention should be paid to the notion, nature, and types of intelligence, as well as which strategies are appropriate to the type of intelligence in which the student is exceling (Al-Saidi, Al-Jahouri, Khataiba, \& Al-Marzouki, 2011, p. 235). The students' possession of a high level of multiple intelligences allows them to identify the problems they face and try to solve them. This group also possesses the ability to analyze and investigate knowledge, as well as be aware of errors and conclusions. They are also good at finding the evidence and proofs of these conclusions (Khalil, Jaljal, Abu Furah, \& al-Najjar, 2013, p. 1099).

A number of studies have examined the status of students' multiple intelligences, including Jawda and Ali (2020), who aimed to diagnose multiple intelligences among middle school students; they applied a scale of intelligence to the study sample of 50 students. The results revealed a high level of interpersonal, spatial and linguistic intelligences among this sample, whereas the level of kinetic, strategic, and emotional intelligence was medium.

Ryan (2013) sought to discover the types of intelligences prevalent among high school students in the Hebron 
Directorate in Palestine. It used a scale and applied it to a sample of 609 male and female students. The results revealed that the common intelligences among the study sample were interpersonal, intrapersonal, verbal, kinesthetic, musical, athletic, spatial, and naturalistic.

Al-Saeedi, et al (2011) aimed to discover the multiple intelligences prevalent among 11th-grade students at Kaab Bin Barsha School in North Al Batinah Governorate. The study used a scale of intelligence on a sample of 175 students. The results showed there are four types of intelligence prevalent in the study, namely linguistic intelligence, logical intelligence, kinetic intelligence, and visual intelligence. The mean of linguistic intelligence reached 44.93 and came in first in terms of prevalence among the study sample. As for the visual intelligence, its mean reached 19.03 and came in fourth. The means of the musical, interactive, and interpersonal intelligences were low compared to the other four.

Abdi, Laei, and Ahmadyan (2013) also showed the effectiveness of using multiple intelligences on academic achievement in a science course. They tested a control group and an experimental group, each consisting of 20 fifth-grade students. The results showed the superiority of the experimental group using teaching strategies based on multiple intelligences.

We can conclude from the literature review examined by this study that the intelligences of the students differ based on the gender variable. Those studies discovered that the interpersonal, logical, linguistic, and visual intelligences were the most prominent in most cases, whereas intrapersonal and musical intelligences were less prevalent among the samples of the studies that examined the multiple intelligences.

The theory of multiple intelligences, a new psychological theory in cognitive psychology, has changed the educators' perceptions of the educational process in general and learners in particular. This theory has proved to be beneficial in educational practices because it develops minds that can handle the changes of the third millennium, activates the educational process, and puts student on the right track (Raslan \& Shehata, 2014, p. 63).

This theory can help teachers plan their lessons and diversify the teaching methods according to students' intelligences. This will lead to stimulating students' motivation toward learning; thus, a required change can be made in their levels of achievement.

\section{Research Problem}

The researchers noted that some teachers do not pay attention to the multiple intelligences of their students and apply one strategy to teach students regardless of their differences in intelligences. The researchers' experience in teaching Arabic language reinforces the importance of examining this problem. The textbooks, methods of teaching, and teachers' guidebooks do not focus on multiple intelligences, and there is a lack of diversification among teaching activities and strategies. The importance of examining this problem has been reinforced by the recommendations of studies conducted in Oman, including Al-Saeedi et al. (2011), who recommended the necessity of discovering students' multiple intelligences before starting the teaching process, as well as Jawda and Ali (2020) and Ryan (2013). Researchers have been motivated to address this problem by the literature results, which have proven the effectiveness of strategies based on multiple intelligences in raising the level of achievement (Abdi et al., 2013; Al-Amouri, 2005).

\section{Research Questions}

This study attempted to answer the following questions:

3.1 Question I: What are the Common Multiple Intelligences among Ninth-grade Students in Al Batinah North Governorate in the Sultanate of Oman?

3.2 Question II: What are the Most Common Intelligences among Ninth-grade Male Students in Al Batinah North Governorate, Sultanate of Oman?

3.3 Question III: What are the Most Common Intelligences among Ninth-grade Female Students in Al Batinah North Governorate, Sultanate of Oman?

3.4 Question IV: Are There Statistically Significant Differences at the Significance Level of $\alpha=0.05$ between the Arithmetic Means of Students in Multiple Intelligences Based on the Gender Variable?

\section{Importance of the Study}

The importance of this study can be summarized as follows: It sheds light on the theory of multiple intelligences, which may help teachers harmoniously apply the various strategies and teaching methods, taking into account the multiple 
intelligences among their students. It motivates curriculum designers and developers to adopt this theory when making the curricula. It may help parents identify the intelligences of their ninth-grade children. The results can be used in designing a database for the prevailing intelligences among the ninth-grade students.

\section{Research Objectives}

This study aimed at the following: (a) preparing a list of the various types of intelligences suitable for ninth grade students; (b) discovering the common multiple intelligences among ninth-grade students in Al Batinah North Governorate in the Sultanate of Oman in general; and (c) identifying the prevailing intelligences among ninth-grade male students in comparison to the prevailing intelligences among female students.

\section{Research Terminologies}

Multiple intelligences can be defined as the following: "Everyone has at least eight types of intelligence as follows: Musical, spatial, bodily, linguistic, logical, interpersonal, intrapersonal, and naturalistic. Each of these intelligences have neural basics in the brain and operate to varying degrees. Each of them is based at first on the biological reasons, then it turns to be linked to genetic and environmental factors" (Tavris \& Wade, 2000, p. 331). In this study, the multiple intelligences are determined by the score obtained by the student in the IQ indicators included in the multiple intelligences scale.

\section{Research Limitations}

Objective limits: This study is limited to discovering the eight types of intelligences: linguistic-verbal, visual-spatial, logical-mathematical, interpersonal, naturalistic, bodily-kinesthetic, intrapersonal, and rhythm-musical.

Spatial limits: This study is restricted to ninth-grade students in the schools of Al Batinah North Governorate only.

Time limits: The study was implemented in the second semester of the 2019/2020 academic year.

\section{Research Methodology and Procedures}

The study procedures included the following:

8.1 The Research Population Consists of Ninth-grade Students in Al Batinah North Governorate: 8,434 Male and Female Students.

8.2 Research Sample: It Consists of 112 Male and Female Students, Which Includes 58 Male and 54 Female Students.

8.3 Research Instrument: Multiple Intelligences Scale Consisting of the Eight Types of Intelligences: Linguistic-verbal, Visual-spatial, Logical-mathematical, Interpersonal, Naturalistic, Bodily-kinesthetic, Intrapersonal, and Rhythm-musical. Each Type of Intelligence Includes Eight Descriptive Items, with a Total of 64 Items for the Scale as a Whole.

8.3.1 Designing a List of the Types of Multiple Intelligences and a Number of Behavioral Indicators Indicating These Types, through Using Various Educational Sources.

8.3.2 Validation of the Instrument: This List has been Peer Reviewed by Six Academics Specializing in Psychology, Curriculum, and Instruction.

8.3.3 The Consistency of the Instrument: The Consistency of the Scale was Validated through Application and Reapplication (over time).

The scale was applied to a random sample of 25 students from Al-Bureek School for grades 1-9, and a random sample of 28 students from Abdullah bin Yahya Al-Kindi School for grades 1-9, with a total of 53 students. The scale was applied again after 2 weeks, and the consistency was measured by the Pearson correlation coefficient and Cronbach's alpha. Table 1 displays the results: 
Table 1. Measurement of the Consistency of the Multiple Intelligences Scale for Ninth-grade Students through the Pearson Correlation Coefficient and Cronbach's Alpha

\begin{tabular}{llll}
\hline \multirow{2}{*}{ Test } & \multicolumn{2}{l}{ Consistency Measurement } \\
\cline { 2 - 4 } & Pearson & $\begin{array}{l}\text { Cronbach's alpha } \\
\text { First application }\end{array}$ & Second application \\
\hline Multiple Intelligences Scale & $0.83 \%$ & $0.71 \%$ & $0.75 \%$ \\
\hline
\end{tabular}

The results in Table 1 indicate that the correlation coefficient between the first application of the scale and the total of the second application amounted to $0.83 \%$, whereas the Cronbach's alpha coefficient for the first application was $0.71 \%$. In the second application, it reached $0.75 \%$, which is suitable for research purposes. Therefore, this result can be used to apply the scale to the research sample. Regarding the statistical methods, the current study used Pearson's correlation coefficient, Cronbach's alpha coefficient, arithmetic means, and standard deviations.

\section{Results of the Research}

To answer the study questions, we used arithmetic means and standard deviations. The answers to our questions are as follows:

Question I: What are the common multiple intelligences among ninth-grade students in Al Batinah North Governorate in the Sultanate of Oman?

Table 2 shows the multiple intelligences among ninth-grade students in Al Batinah North Governorate.

Table 2. Arithmetic Means and Standard Deviations of the Responses of Ninth-grade Students in Al Batinah North Governorate on the Areas of Multiple Intelligences Scale

\begin{tabular}{llll}
\hline Type of Intelligence & Arithmetic Means & Standard Deviations & Rank \\
\hline Verbal-linguistic & 0.67 & 0.19 & 4 \\
Spatial-visual & 0.67 & 0.16 & 3 \\
Mathematical-logical & 0.70 & 0.26 & 2 \\
Interpersonal & 0.75 & 0.19 & 1 \\
Naturalistic & 0.67 & 0.20 & 5 \\
Kinetic-athletic & 0.64 & 0.22 & 7 \\
Intrapersonal & 0.52 & 0.20 & 8 \\
Rhythm-musical & 0.65 & 0.36 & 6 \\
Intelligences as a whole & 0.66 & 0.12 & \\
\hline
\end{tabular}

Table 2 shows that the arithmetic means of the sample reached 0.75 for interpersonal intelligence, which came in first place in terms of its prevalence among the ninth-grade students. Table 2 also shows that the arithmetic means of logical intelligence reached 0.70 , coming in second place. As for visual-spatial intelligence, its arithmetic mean was 0.67 and ranked third in terms of prevalence among the study sample. The linguistic intelligence ranked fourth, and its arithmetic mean was 0.67. The last four ranks were distributed as follows from the highest rank and the lowest according to the arithmetic means of the study sample: naturalistic, musical, bodily-kinesthetic, and intrapersonal. The result of this study was different from the results of Al-Saeedi et al. (2011), who showed that linguistic intelligence was ranked first in terms of prevalence, followed by bodily-kinesthetic intelligence. The two studies agreed on ranking the intrapersonal intelligence last.

Question II: What are the most common intelligences among the ninth-grade male students in Al Batinah North Governorate, Sultanate of Oman?

To answer this question, this study used arithmetic means and standard deviations. Table 3 shows answers to the question: 
Table 3. Arithmetic Means and Standard Deviations of the Responses of Ninth-grade Male Students in Al Batinah North Governorate on the Areas of the Multiple Intelligences Scale

\begin{tabular}{llll}
\hline Type of Intelligence & Arithmetic Means & Standard Deviations & Rank \\
\hline Verbal-linguistic & 0.67 & 0.19 & 4 \\
Spatial-visual & 0.62 & 0.15 & 6 \\
Mathematical-logical & 0.68 & 0.17 & 2 \\
Interpersonal & 0.77 & 0.18 & 1 \\
Naturalistic & 0.68 & 0.19 & 3 \\
Kinetic-athletic & 0.61 & 0.16 & 7 \\
Intrapersonal & 0.47 & 0.20 & 8 \\
Rhythm-musical & 0.63 & 0.38 & 5 \\
Intelligences as a whole & 0.64 & 0.11 & \\
\hline
\end{tabular}

Table 3 indicates that the most common intelligence among male students was also interpersonal intelligence, with an arithmetic mean of 0.77 . It was followed by mathematical-logical intelligence, with an arithmetic mean of 0.68 in second place. As for the naturalistic intelligence, it ranked third, with an arithmetic means of 0.68. Linguistic intelligence was ranked fourth with an arithmetic mean of 0.67 . The last four ranks were as follows: musical, visual, kinesthetic, and intrapersonal, from high to low, according to the arithmetic mean scores of the male students. The results of this study differed with the results of Al-Saeedi et al. (2011), who showed that linguistic intelligence came first in terms of the level of prevalence. They agreed with the mathematical logical intelligence, as they ranked it second in terms of prevalence among male students. They also agreed in ranking intrapersonal intelligence last.

Question III: What are the most common intelligences among the ninth-grade female students in Al Batinah North Governorate, Sultanate of Oman?

Arithmetic means and the standard deviations of the responses of ninth-grade female students in Al Batinah North Governorate on the areas of multiple intelligences scale were used to answer this question. Table 4 shows the arithmetic means and standard deviations of the students' responses to the multiple intelligences scale.

Table 4. The Arithmetic Means and Standard Deviations of the Female Students' Responses to the Multiple Intelligences Scale

\begin{tabular}{llll}
\hline Type of Intelligence & Arithmetic Means & Standard Deviations & Rank \\
\hline Verbal-linguistic & 0.67 & 0.18 & 5 \\
Spatial-visual & 0.72 & 0.16 & 2 \\
Mathematical-logical & 0.72 & 0.33 & 3 \\
Interpersonal & 0.73 & 0.19 & 1 \\
Naturalistic & 0.67 & 0.21 & 6 \\
Kinetic-athletic & 0.68 & 0.27 & 4 \\
Intrapersonal & 0.57 & 0.19 & 8 \\
Rhythm-musical & 0.66 & 0.34 & 7 \\
Intelligences as a whole & 0.68 & 0.12 & \\
\hline
\end{tabular}

Table 4 indicates that the most common intelligence among female students was interpersonal intelligence, with an arithmetic mean of 0.73 . It was followed by visual-spatial, with an arithmetic mean of 0.72 in second place. As for the logical-mathematical intelligence, it ranked third, with an arithmetic mean of 0.72 . The bodily-kinesthetic intelligence ranked fourth, with an arithmetic mean of 0.68. The last four ranks were as follows: linguistic, naturalistic, musical, and intrapersonal, according to the arithmetic means of the grades of the female students. The results of this study are consistent with Jawda and Ali (2020), who showed that interpersonal intelligence ranked first in terms of prevalence among female students, followed by visual-spatial intelligence, whereas it differed in the results of the prevalence of linguistic intelligence, as it was ranked third in Jawda and Ali (2020).

Question IV: Are there statistically significant differences at the significance level of $\alpha=0.05$ between the arithmetic means of students in multiple intelligences based on the gender variable?

Table 5 illustrates the significance of the differences between the responses of the sample individuals on the multiple intelligences scale, according to the gender variable. 
Table 5. The Significance of the Differences between the Responses of the Sample Individuals on the Multiple Intelligences Scale, according to the Gender Variable

\begin{tabular}{|c|c|c|c|c|c|c|c|}
\hline Field & Gender & Number & $\begin{array}{l}\text { Arithmetic } \\
\text { Means }\end{array}$ & $\begin{array}{l}\text { Standard } \\
\text { Deviations }\end{array}$ & $\begin{array}{l}\text { Degree } \\
\text { of } \\
\text { Freedom }\end{array}$ & P-Value & $\begin{array}{l}\text { Significance } \\
\text { Level }\end{array}$ \\
\hline \multirow{3}{*}{ Verbal-linguistic } & Male & 58 & 0.67 & 0.19 & 110 & & \\
\hline & female & 54 & 0.67 & 0.18 & 110 & 0.156 & 0.876 \\
\hline & Male & 58 & 0.62 & 0.15 & 110 & & \\
\hline \multirow[t]{2}{*}{ Spatial-visual } & female & 54 & 0.72 & 0.16 & 110 & 3.375 & $0.001 *$ \\
\hline & Male & 58 & 0.68 & 0.17 & 110 & & \\
\hline \multirow{2}{*}{ Mathematical-logical } & female & 54 & 0.72 & 0.33 & 110 & 0.897 & 0.372 \\
\hline & Male & 58 & 0.77 & 0.18 & 110 & & \\
\hline \multirow[t]{2}{*}{ Interpersonal } & female & 54 & 0.73 & 0.19 & 110 & 1.333 & 0.185 \\
\hline & Male & 58 & 0.68 & 0.19 & 110 & & \\
\hline \multirow[t]{2}{*}{ Naturalistic } & female & 54 & 0.67 & 0.21 & 110 & 0.317 & 0.752 \\
\hline & Male & 58 & 0.61 & 0.16 & 110 & & \\
\hline \multirow[t]{2}{*}{ Kinetic-athletic } & female & 54 & 0.68 & 0.27 & 110 & 1.641 & 0.104 \\
\hline & Male & 58 & 0.47 & 0.20 & 110 & & \\
\hline \multirow[t]{2}{*}{ Intrapersonal } & female & 54 & 0.57 & 0.19 & 110 & 2.798 & $0.006 *$ \\
\hline & Male & 58 & 0.63 & 0.38 & 110 & & \\
\hline \multirow{3}{*}{$\begin{array}{l}\text { Rhythm-musical } \\
\text { Intelligences as a } \\
\text { whole }\end{array}$} & female & 54 & 0.66 & 0.34 & 110 & 0.417 & 0.678 \\
\hline & Male & 58 & 0.64 & 0.11 & 110 & & \\
\hline & female & 54 & 0.68 & 0.12 & 110 & 1.628 & 0.106 \\
\hline
\end{tabular}

* Statistically significant at the 0.05 level.

It is evident from the data of the previous table that there are statistically significant differences at the 0.05 significance level between the male and female students in the fields of visual-spatial and intrapersonal intelligence in favor of women. The t-value in the visual-spatial intelligence field was 3.375, and, in the field of personal intelligence, the t-value was 2.798, whereas no statistically significant differences appeared at the 0.05 level between the male and female students in the rest of the areas of multiple intelligences and in the whole scale.

The results of this study were consistent with Hawda, Ali, and al-Dahab (2012), relating to the presence of differences between men and women in personal intelligence in favor of women and in the absence of statistically significant differences between men and women in musical, bodily-kinesthetic, and visual intelligence. The two studies differ in the existence of differences between men and women in logical-mathematical and linguistic and intrapersonal intelligence in favor of women, and in the presence of differences in interpersonal intelligence in favor of men.

\section{Discussion and Interpretation of the Results}

The interpersonal, logical, mathematical, and spatial intelligences received the first ranks in terms of the level of prevalence among the study sample in general (male and female) and among the female sample in particular. These results can be explained by the effect of social media in developing these types of social intelligences and providing multiple opportunities for students to communicate and interact with their surrounding environment. The Islamic values and religious teachings instill the importance of communication and interaction with relatives and peers. In addition to that, social media platforms provide several audio-visual options for users to interact with. All these factors may have contributed to the prevalence of these intelligences among the study sample. Al-Aqeel and Abdul-Jawaldeh (2018, p. 58) stated that the various opportunities for social growth, communication, and interaction with social environments, schools, society, and traditions are among the reasons for the prevalence of social intelligence among students.

The interpersonal, logical, mathematical, and naturalistic intelligences received the highest ranks in terms of prevalence among male students. This result can be attributed to the previous reasons, in addition to the fact that men naturally tend to deal with situations logically, and not emotionally, as well as being widely involved in society and playing a prominent social role. This could be also attributed to the nature of the society, which deals with men in a different way from women to prepare them for future tasks and responsibilities (Shahrour, 2015, p. 130).

There are statistically significant differences between men and women in visual and intrapersonal intelligence in favor 
of women. This result can be explained in the peculiarity of the nature of students, which tend to employ learning visual stimuli more than other means due to the special nature of women. This may also be attributed to the fact that this sample uses the left side of the brain more than the right side. Visual thinking is related to the left side of the brain because it is responsible for holistic perception, assembly, and visual learning (Amer \& Al-Masry, 2016, p. 200).

\section{Study Recommendations and Proposals}

In light of the findings of this study, the following recommendations and proposals can be made: (a) Apply multiple intelligences scales at the beginning of each academic year, classify students according to their intelligence to build and implement lesson plans in light of these classifications, and deal with students according to their differences in the multiple intelligences while designing the curricula and assessment tools; (b) train teachers on the theory of multiple intelligences and apply it through workshops, seminars, and training courses; (c) diversify the learning environment according to the differences of intelligences among students; (d) prepare educational curricula according to the students' multiple intelligences and develop them in light of educational developments while taking into account the differences among students; (e) conduct diagnostic studies for the prevalent multiple types of intelligences among all students in all classes and educational stages; and (f) conduct studies that test the effectiveness of employing the theory of multiple intelligences and its educational applications in developing language and personal skills and academic achievement.

\section{References}

Abdi, A., Laei, S., \& Ahmadyan, H. (2013). The effect of teaching strategy based on multiple intelligences on students' academic achievement in science course. Universal Journal of Educational Research, 1(4), 281-284.

Al-Amouri, F. A. M. (2005). Impact of teaching strategies based on the theory of multiple intelligences on female students' achievement and attitudes toward chemistry [Unpublished master's thesis]. Sultan Qaboos University.

Al-Aqeel, A. T., \& Abdul-Jawaldeh, F. (2018). The differences in social and emotional intelligence between ordinary students and those with learning difficulties. Educational Science Studies, 4(45), 43-61. https://doi.org/10.35516/0102-045-986-003

Al-Hashemi, A.-R., \& Al-Dulaimi, T. H. (2008). Modern strategies in the art of teaching. Al Shurouq House for Publishing and Distribution.

Al-Hashemi, A.-R., \& Maharmah, S. M. (2014). Arabic language and the theory of multiple intelligences. Al E'asar Al Elimi House for Publishing and Distribution.

Al-Saeedi, A. A., Al-Jahwari, N. A., Khatayeba, A. M., \& Marzouqi, A. A. (2011). Multiple intelligences patterns among twelfth-grade students at Kaab bin Barsha School of General Education in the Sultanate of Oman and their relationship to students' achievement in chemistry. Journal of Educational and Psychological Sciences, 2(12), 230-255. https://doi.org/10.12785/JEPS/120208

Al-Zahrani, M. S. M. (2003). Strategies to discover talented and creative people; between originality and modernity. Taiyba Al Khadra Publishing House.

Amer, T. A.-R., \& Al-Masry, I. I. (2016). Visual thinking: Its concept - its skills - its strategies. Arab Group for Training and Publishing.

Armstrong, T. (2009). Multiple intelligences in the classroom. ASCD.

Armstrong, T., \& Association for Supervision and Curriculum Development 2018. (2018). Multiple intelligences in the classroom (4th ed.). ASCD.

Gardner, H., \& Moran, S. (2006). The science of multiple intelligences theory: A response to Lynn Waterhouse. Educational Psychologist, 41(4), 227-232. https://doi.org/10.1207/s15326985ep4104_2

Hawda, F. M. A., Ali, N. A. A., \& al-Dahab, M. H. M. (2012). Multiple intelligences among a sample of secondary school students: A comparative study. Journal of Children Studies, 57(15), 107-110.

Hussein, M. A. A. H. (2013). Multiple intelligences among middle school students. Alqira'h Walm'erfh Journal, 154, 53-64.

Hussein, M. A. Ab. (2013). Multiple intelligences for middle school students. Reading and Knowledge Journal, 154, 53-64. 
Jawda, H. A. N. M., \& Ali, M. S. I. (2020). Diagnosis of multiple intelligences among some middle school students. Scientific Journal of Physical Education and Sports Sciences, 37, 25-39.

Khalil, M. I. a-S., Jalil, N. M. A. M., Abu Furah, K. Q. M., \& al-Najjar, A. a-D. a-S. A.-J. (2013). The relationship between multiple intelligences and contemplation among primary school students. Journal of the College of Education, 2(18), 1103-1073.

Nolen, J. L. (2003). Multiple intelligences in the classroom. nEducation, 124(1), 115-119.

Raslan, M., \& Shehata, S. (2014). Multiple intelligences among middle school students. Alqira'h Walm'erfh Journal, 154, 53-64.

Ryan, A. A. (2013). Types of multiple intelligences among high school students in the Hebron Education Directorate in Palestine. Al-Aqsa University Journal, 1(17), 193-234.

Shahrour, A. G. (2015). Multiple intelligences and its relationship to self-efficacy in classroom management among teachers of gifted and ordinary students. Dar Wae'l for Publishing.

Tavris, C., \& Wade, C. (2000). Psychology (6th ed.). New Jersey, NJ: Prentice Hall.

\section{Copyrights}

Copyright for this article is retained by the author(s), with first publication rights granted to the journal.

This is an open-access article distributed under the terms and conditions of the Creative Commons Attribution license (http://creativecommons.org/licenses/by/4.0/). 